\title{
OPTIMIZING CHLORELLA VULGARIS AND ANABAENA VARIABILIS GROWTH CONDITIONS FOR USE AS BIOFUEL FEEDSTOCK
}

\author{
N.J. TARIN ${ }^{1}$, N.M. ALI ${ }^{1}$, A.S. CHAMON ${ }^{1}$, M.N. MONDOL ${ }^{1 *}$, \\ M.M. RAHMAN ${ }^{1}$ AND A. AZIZ \\ ${ }^{1}$ Department of Soil, Water and Environment, ${ }^{2}$ Department of Botany, University of \\ Dhaka, Dhaka 1000, Bangladesh
}

\begin{abstract}
Isolation and characterization of Chlorella vulgaris (green alga) and Anabaena variabilis (cyanobacterium) were made from natural and artificial water bodies of Dhaka University and Khulna, Bangladesh from March through December 2014 using modified Chu-10D medium to determine their potential as feedstock for biofuel production. Optimum growth measured as total chlorophyll and optical density under varying physical and chemical environments was determined. The optimum growth for $C$. vulgaris was obtained at $\mathrm{pH} 6.5$ under light intensity of $110 \mu \mathrm{E} \mathrm{m}^{-2} \mathrm{~s}^{-1}$ and one and a half times the concentration of the Chu-10D. Compared to this, the optimum growth for $A$. variabilis was obtained at $7.0 \mathrm{pH}, 90 \mu \mathrm{E} \mathrm{m}^{-2} \mathrm{~s}^{-1}$ light intensity and normal Chu 10D. Both organisms were grown at $25^{\circ} \mathrm{C}$ temperature. Aeration of medium showed a significant positive growth for both the isolates. Supplementation of medium with vitamin $\mathrm{B}_{1}, \mathrm{~B}_{6}, \mathrm{~B}_{7}$ and $\mathrm{B}_{12}$ would yield higher biomass of $C$. vulgaris as biofuel feedstock. Vitamins were not required for growing A. variabilis.
\end{abstract}

Key words: Microalgae, Chlorella vulgaris, Anabaena variabilis, Feedstock, Biofuel, Growth optimization

\section{Introduction}

Rising concern over depleting fossil fuel and greenhouse gas emissions has resulted in high level of interest in non-conventional fuel like biodiesel and bioethanol originating from bio-renewable sources including sugars, starches and ligno-cellulosic materials from solid wastes and plant biomass including algal biomass. Microalgae in particular have been reported to have several advantages which include high productivity, no competition with conventional agricultural land, utilization of waste water, brackish water and sea water, recycling of carbon dioxide, and compatibility with integrated production of fuels and co-products within bio-refineries such as agar, dye stuff, protein rich animal feed etc. (Sahoo et al. 2012 and Kumar et al. 2013).

Although the first-generation bioethanol production from food crops such as corn, grain, or sugar cane is well established and the industry is growing throughout the world, the use of these staple food crops as feedstock is not ideal because of the high price of raw

${ }^{*}$ Corresponding author: mondol-bangladesh@ @otmail.com 
materials, which account for almost $40-75 \%$ of total ethanol production cost (Jang et al. 2012). It has raised doubts about its possible impact on food supply and security, which is mainly reduced if its residues are used for bioethanol production (Song et al. 2013). In contrast, the second-generation bioethanol is derived from ligno-cellulosic feedstock. Currently, no commercial-scale cellulosic ethanol plants are in operation largely because of the high price of production, which is almost twice that of corn ethanol (Jones and Mayfield 2012). In view of the aforementioned issues, microalgae are gaining wide attention as an alternative renewable source of biomass for the production of biofuel, which is grouped under 'third-generation bioethanol' (Nigam and Singh 2011).

Certain species of microalgae have the ability to produce high levels of carbohydrates as reserve polymers instead of lipids. These species are ideal for the production of bioethanol as carbohydrates produce fermentative sugars. It has been estimated that approximately 46760-140290 L/ha ethanol can be produced from microalgae (Nguyen and $\mathrm{Vu}$ 2012). This yield is several orders of magnitude larger than the yields obtained from corn, soybean, etc. (Lombardi and Maldonado 2011). Green algae including Spirogyra and Chlorococcum were reported to accumulate high levels of polysaccharides both in their complex cell walls and as starch (Nigam and Singh 2011). This starch accumulation can be used in the production of bioethanol (Harun et al. 2010). Bioethanol is used in fuel mixtures such as E85 (a blended fuel of 85\% ethanol and 15\% gasoline) in Brazil and USA (Davis et al. 2000).

In Bangladesh, a large number of algal species were reported to occur in freshwater, brackish water and marine habitats (Web 1, Ahmed et al. 2008) which could be potential sources of biofuel feedstock, but the potential of algal biomass production for biofuel has not been properly addressed. Therefore, the present research was initiated to identify probable potential microalgae of Bangladesh for using as biofuel feedstock by optimizing their growth conditions.

\section{Materials and Methods}

Isolation of microalgae: Water samples with algal boom were taken in to plastic bottles as well as in glass vials containing sterilized modified Chu-10D medium (Aziz and Whitton 1987 adapted from Chu-10D of Sinclair and Whitton (1977) by a dropper from different fountains, ponds, ditches, etc. located at Dhaka University campus and Khulna for obtaining fast growing and frequently occurring microalgae. The liquid medium used in this study is not an absolute inorganic medium as two organic compounds, the EDTA as a chelating agent and HEPES as a buffer were used. Four vitamins i.e. $\mathrm{B}_{1}, \mathrm{~B}_{6}, \mathrm{~B}_{7}, \mathrm{~B}_{12}$ in six combinations i.e. $\mathrm{B}_{1}+\mathrm{B}_{6}, \mathrm{~B}_{1}+\mathrm{B}_{7}, \mathrm{~B}_{1}+\mathrm{B}_{12}, \mathrm{~B}_{7}+\mathrm{B}_{12}, \mathrm{~B}_{1}+\mathrm{B}_{7}+\mathrm{B}_{12}$ and $\mathrm{B}_{1}+\mathrm{B}_{6}+\mathrm{B}_{7}+\mathrm{B}_{12}$ with a control in each case were used to find out their effects.

Unialgal culture was obtained by repeated subculturing in liquid and solid agar media using platinum wire loop or sterile Pasture pipette. In some cases, series of dilutions were 
made in sterile medium using homogenized suspension of algae. Unialgal condition was confirmed by compound microscope.

Green algae and cyanobacteria of 8 to 30 days old cultures were used for microscopic study, described, photographed and identified following Ahmed et al. (2008), Starmach (1966) and Desikachary (1959) and Siddiqui et al. (2007).

Maintenance and subculture: The present experiments were conducted in the controlled growth room of National Professor KM Nurul Islam laboratory, Department of Botany, DU. Stock cultures were maintained in $30 \mathrm{ml}$ liquid medium in the controlled growth room with an average temperature of $25^{\circ} \mathrm{C}$ under continuous low light of ca. $40 \mu \mathrm{E}$ $\mathrm{m}^{-2} \mathrm{~s}^{-1}$ provided by cool white fluorescent light from glass bottom. Subculture was made after about every three months. Stock cultures for experimentation were inoculated under a continuous average light flux of $71 \mu \mathrm{E} \mathrm{m}^{-2} \mathrm{~s}^{-1}$ and 4-7 days old culture was used as inoculum. Each treatment had four replicates and were randomized after every $24 \mathrm{hr}$.

Estimation of growth: Growth was estimated by measuring chlorophyll(s) and Optical density (O.D.). Chlorophyll $a$ and $b$ for Chlorella vulgaris were estimated following APHA (American Public Health Association 1985), only chl a for Anabaena variabilis following Marker et al. (1980) and O.D. in both cases by measuring absorbance at 750 $\mathrm{nm}$ wave length in spectrophotometer following Rodolfi et al. (2009).

pH was measured using Hanna pocket model and average light flux by Li-Cor, USA, using aerial probe. Temperature was measured by maximum-minimum wall thermometer.

Aeration: Aeration of the culture-flasks was done to optimize the effect of bubbling on algal growth (for $\mathrm{CO}_{2}$ utilization) at a pressure of $0.0067 \mathrm{M} \mathrm{Pa}$ using an aquarium air pump with a pumping capacity of $8 \mathrm{~L} \mathrm{~min}^{-1}$ at $25 \pm 1^{\circ} \mathrm{C}$ temperature and at an average light flux of $71 \mu \mathrm{E} \mathrm{m}^{-2} \mathrm{~s}^{-1}$.

The standard deviations were done to measure the sample variations, analysis of variance (ANOVA) of the data was computed to determine the F-value and test of significance was computed by Duncan's New Multiple Range Test (DMRT) in IBM SPSS statistics version 22 .

\section{Results and Discussion}

Chlorella vulgaris (Class: Chlorophyceae, Order: Chlorococcales, Family: Chlorellaceae, Genus: Chlorella) and Anabaena variabilis (Class: Cyanobacteria, Order: Nostocales, Family: Nostocaceae, Genus: Anabaena) were isolated from freshwater bodies and characterized as follows: 
Chlorella vulgaris Beyer (Figs. 1a-c) (Ahmed et al. 2008)

Cell solitary or in small colony of indefinite shape; Individual cells spherical to broadly oval; Cell wall thin; Chloroplast massive cup-shaped, parietal with indistinct pyrenoid; Cell 6.5-7.5 $\mu \mathrm{m}$ long, 6.0-8.0 $\mu \mathrm{m}$ broad. Collected from TSC fountain, Dhaka University, planktonic

Anabaena variabilis Kütz. ex Born. et Flah (Figs. 1d-f) (Siddiqui et al. 2007)

Thallus gelatinous; cells barrel-shaped, constricted at the cross walls, 4.5-6.0 $\mu \mathrm{m}$ broad, 5.4-6.5 $\mu \mathrm{m}$ long; end cells conical; heterocysts intercalary, oval, 7.5-12.0 $\mu \mathrm{m}$ broad, 7.8$10.8 \mu \mathrm{m}$ long; akinete not differentiated in the present observation with 30 days old culture. Collected from a pond, Khulna University.

\section{Optimization of growth conditions}

Chlorella vulgaris grew better, measured as chlorophylls at pH 6.5 followed by 6.0. Growth at neutral and alkaline pH were significantly lower (Fig. 1). Mayo (1997)
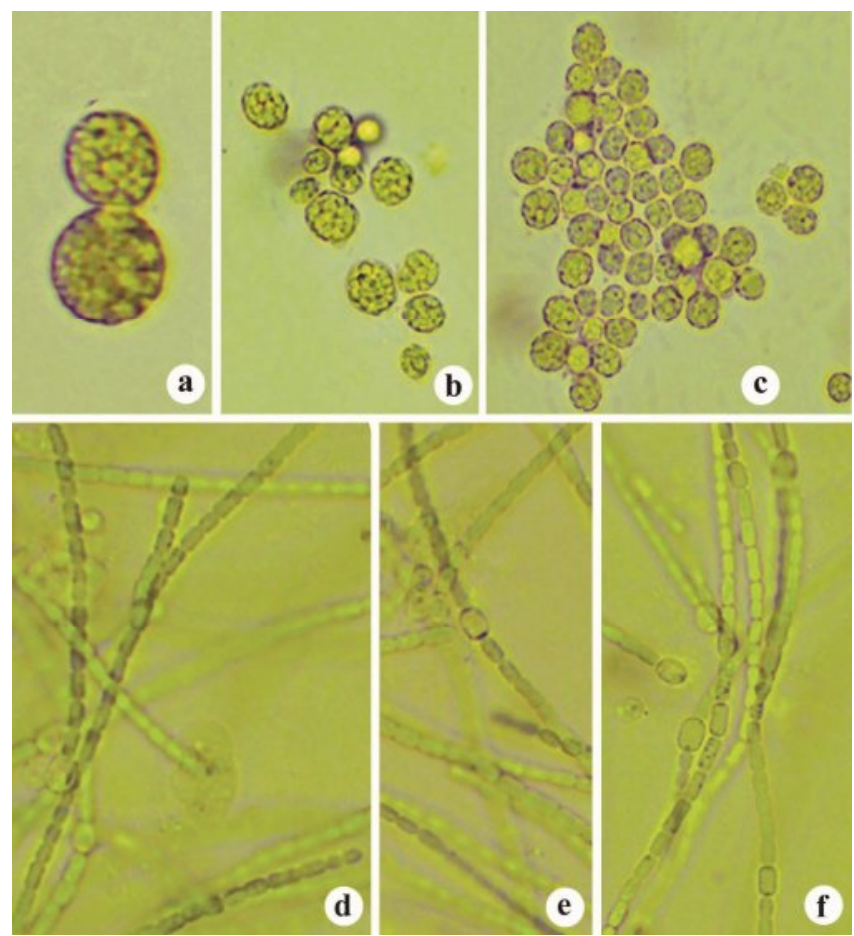

Plate 1. Chlorella vulgaris: a) Two associated cells enlarged showing nemerous starch granules around a pyrenoid; b) cells of various shape and size at lower magnification, smaller ones are released autospores; c) mature cells many having one pyrenoid in each cell and surrounding starch grains. d-f. Anabaena variabilis: d) young filaments as hormogonia, e) hormogonia and a mature filament with heterocyst, f) only mature filaments. 
observed maximum growth more or less at $6.5 \mathrm{pH}$ in Chlorella $\mathrm{sp}$. In C. vulgaris a complete inactivation at acidic $\mathrm{pH}$ was found (Carberry and Brunner 1991). However, Anabarna variabilis had best growth at $7.0 \mathrm{pH}$ (Fig. 3) which was similar to the findings of Yoon et al. (2008). In the same species Nagle et al. (2010) observed growth inhibition at $<5.0$ and $>10.5 \mathrm{pH}$. The present organism also was severely affected at lower and much higher $\mathrm{pH}$ (Fig. 2).

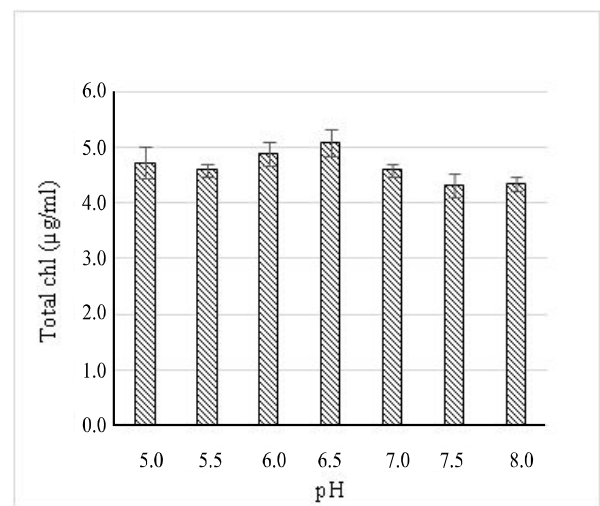

Fig. 1. Effect of $\mathrm{pH}$ on the growth as total chlorophyll (chl $a$ and $b$ ) of Chlorella vulgaris. Significant at $5 \%$ level.

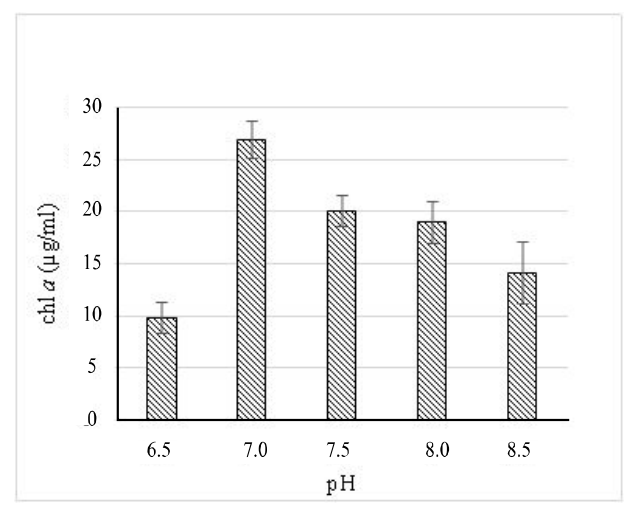

Fig. 2. Effect of $\mathrm{pH}$ on the growth as chlorophyll (chl a) of Anabaena variabilis. Significant at 5\% level.

Chlorella vulgaris had best growth as optical density at $110 \mu \mathrm{E} \mathrm{m}^{-2} \mathrm{~s}^{-1}$ (Fig. 3). It is possible that continuous exposure of the cells under adequate light energy, in particular, during cell division process, $C$. vulgaris is able to grow faster. Similar observations were reported by Wijanarko et al. (2004) and Sharma et al. (2012). Best growth was in Anabaena variabilis observed at a light flux of $90 \mu \mathrm{E} \mathrm{m}^{-2} \mathrm{~s}^{-1}$ (Fig. 4).

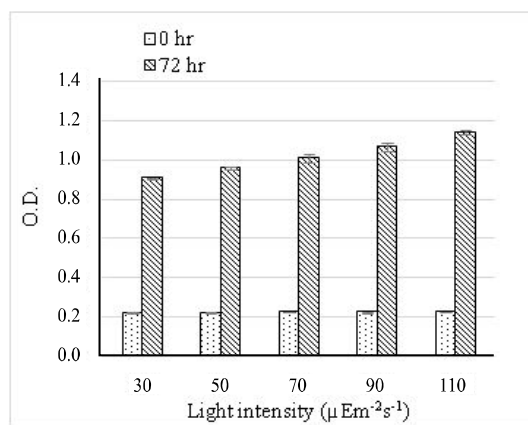

Fig. 3. Effect of light intensity on the growth of Chlorella vulgaris. Significant at $5 \%$ level.

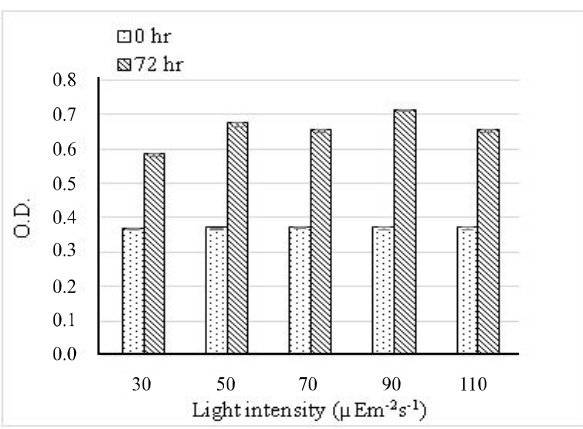

Fig. 4. Effect of light intensity on the growth of Anabaena variabilis. Significant at $5 \%$ level. 
Temperature: Both $C$. vulgaris and A. variabilis responded similarly to temperature variations, highest growth as O.D. was found at $25^{\circ} \mathrm{C}$ and lowest at $35^{\circ} \mathrm{C}$ after $72 \mathrm{hr}$ of incubation (Figs 6-7). Temperature ranging from 25 to $30^{\circ} \mathrm{C}$ was suggested to be favourable for the overall growth of $C$. vulgaris (Sharma et al. 2012). Specific growth rate of $C$. pyrenoidosa, increased uniformly with enhanced temperature, in the range $22^{\circ}$ $\mathrm{C}$ to $30^{\circ} \mathrm{C}$ but dropped at higher temperature and cells were unable to grow above $33^{\circ}$ C (Ong et al. 2010). In A. variabilis and A. nidulans, Sato et al. (1979) obtained about double the cell growth at $25^{\circ} \mathrm{C}$ temperature.

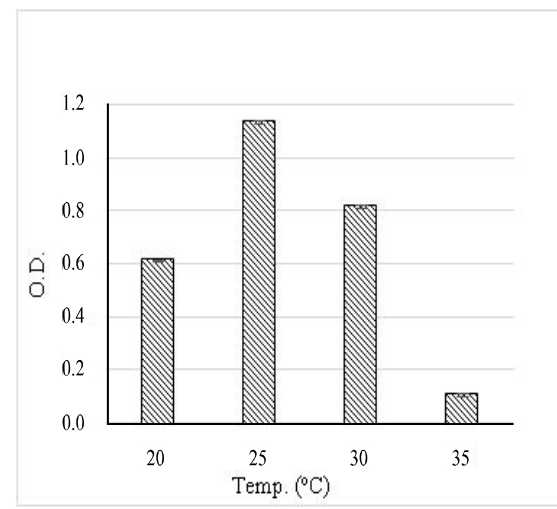

Fig. 5. Effect of temperature on the growth of Chlorella vulgaris.

Significant at 5\% level.

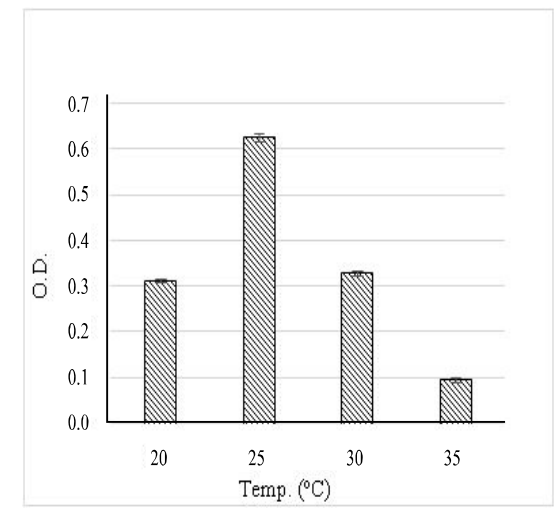

Fig. 6. Effect of temperature on the growth of Anabaena variabilis. Significant at 5\% level.

Aeration: Effects of aeration for $72 \mathrm{hr}$ on growth of C. vulgaris and A. variabilis are presented in Fig. 7. O.D. of the two algae increased by $81 \%$ and $90 \%$, respectively due to bubbling for $72 \mathrm{hr}$. The positive effect was due to the utilization of $\mathrm{CO}_{2}$ and continuous contact of organisms with the medium thereby helping nutrient absorption. These findings are similar to the works reported by Pirt and Pirt (1980) and Berberoğlu et al. (2008) on C. vulgaris and A. variabilis, respectively.

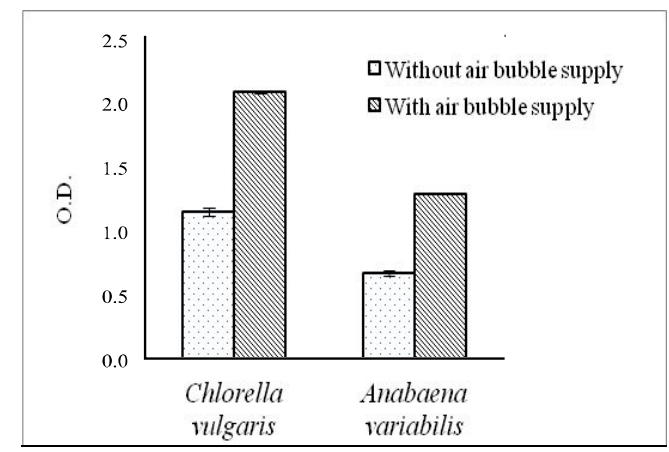

Fig. 7. Effects of air bubbling on the growth of two microalgae. Significant at $5 \%$ level. 
Nutrient element concentration of Chu 10D: Chu 10D medium has relatively low concentration of elements compared to Bold's Basal Medium, in some cases less than half. Therefore, Chu 10D medium concentration was increased by one and one half and doubled. Increased nutrient status had significantly different effects on the growth as O.D. of both the organisms after 48 to $72 \mathrm{hr}$ growth (Figs 8-9). Both the organisms were affected at double the strength of $\mathrm{Chu} 10 \mathrm{D}$. Of the three concentrations $C$. vulgaris showed maximum growth at one and one half strength (Fig. 8) whereas A. variabilis showed maximum at normal Chu 10D strength (Fig. 9). The maximum in A. variabilis might be due to optimum concentration of nutrient elements in normal Chu 10D except nitrogen and the cyanobacterium supplemented it by fixing atmospheric $\mathrm{N}_{2}$ (Stewart and Gallon 1980). At normal Chu 10D strength on the other hand C. vulgaris showed lowest growth and was most likely due to low nitrogen medium and inability of the organism to fix atmospheric $\mathrm{N}_{2}$. However, Chia et al. (2013) showed that the growth obtained in $C$. vulgaris grown in the Chu-10D medium was the highest. Elser et al. (1990) suggested that $\mathrm{N}$ (also $\mathrm{P}$ ) potentially limits algal growth where $\mathrm{N}$-fixing cyanobacterium Anabaena has the ability to fix atmospheric $\mathrm{N}_{2}$ when the water becomes $\mathrm{N}$-depleted.

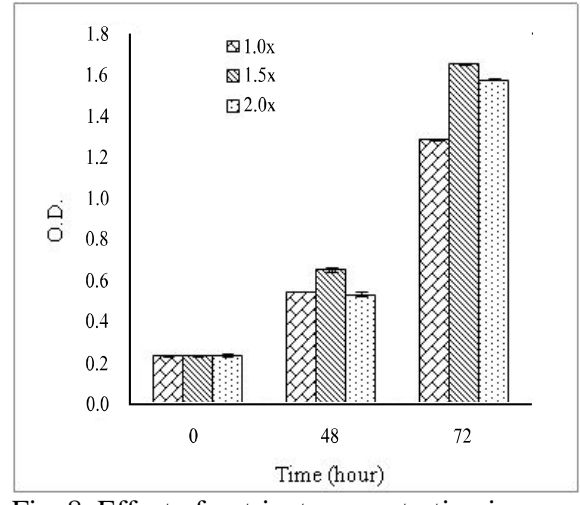

Fig. 8. Effect of nutrient concentration in medium on the growth of chlorella vulgaris.

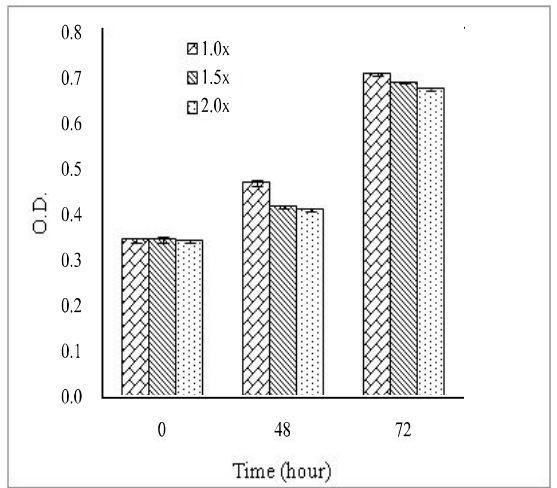

Fig. 9. Effect of nutrient concentration in medium on the growth of $A$. variabilis.

Vitamin supplement: Effect of vitamin $\mathrm{B}_{6}$ alone or in combination with $\mathrm{B}_{1}, \mathrm{~B}_{7}$ and $\mathrm{B}_{12}$ for Chlorella vulgaris is (Fig. 10). Therefore, supplementation of medium with vitamin $\mathrm{B}_{1}$, $\mathrm{B}_{6}, \mathrm{~B}_{7}, \mathrm{~B}_{12}$ would yield higher biomass as feed stock for producing biofuel. In marine diatom Chaetoceros calcitrans vitamin $\mathrm{B}_{6}$ addition also increased growth (Krichnavaruk et al. 2005). Anabaena variabilis does not require any vitamins and produced higher biomass after $72 \mathrm{hr}$ growth than Chlorella vulgaris (Fig. 11). 


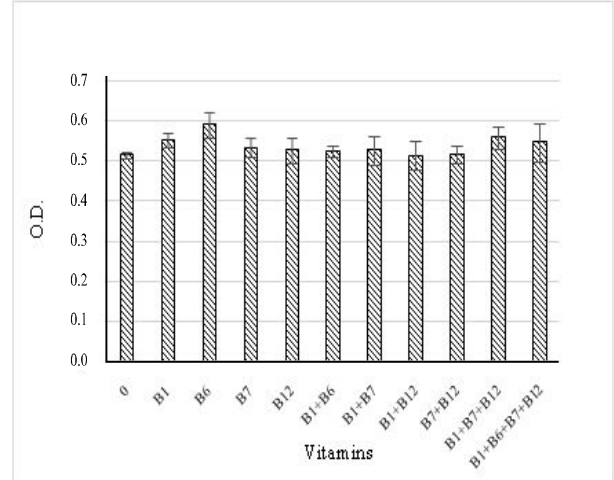

Fig. 10. Effect of vitamins on the growth of Chlorella vulgaris. Significant at $5 \%$ level.

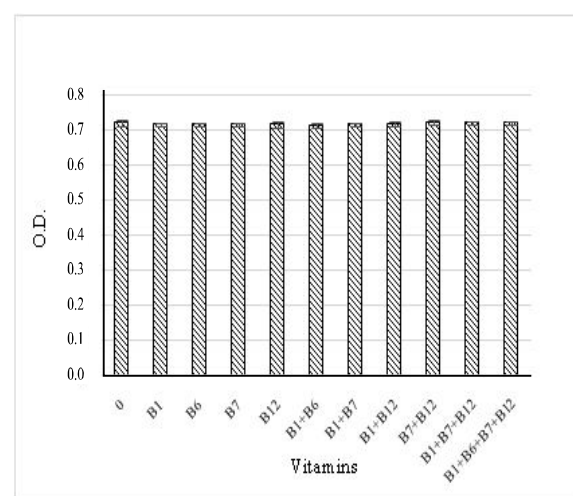

Fig. 11. Effect of vitamins on the growth of Anabaena variabilis. Significant at $5 \%$ level.

\section{Acknowledgments}

Authors gratefully acknowledge the financial support from Centre for Advanced Studies and Research in Biological Sciences, University of Dhaka for carrying out the research and the Department of Botany, University of Dhaka for providing laboratory facilities.

\section{References}

Ahmed, Z.U., Z.N.T. Begum, M.A. Hassan, M. Khondker, S.M.H. Kabir, M. Ahmed, A.T.A. Ahmed, A.K.A. Rahman and E.U. Haque (eds.). 2008. Encyclopedia of Flora and Fauna of Bangladesh. Vol. 3. Algae, Chlorophyta. Asiat. Soc. Bangladesh, Dhaka. pp. 591-592.

APHA. 1985. Standard Methods for the Examination of Water and Wastewater. American Public Health Association.Washington D.C. pp. 268.

Aziz, A. and B.A. Whitton. 1987. Morphogenesis of Blue-Green Algae. I. Filament Development in Gloeotrichia. Bangladesh J. Bot. 16(1): 69-81.

Berberoğlu, H., N. Barra, L. Pilon and J. Jay. 2008. Growth, $\mathrm{CO}_{2}$ Consumption and $\mathrm{H}_{2}$ Production of Anabaena variabilis ATCC 29413-U Under Different Irradiances and $\mathrm{CO}_{2}$ Concentrations. J. Appl. Microbiol. 104: 105-121.

Carberry, J.B. and C.M. Brunner. 1991. Predictions of Diurnal Fluctuations in An Algal-Bacterial Clay Wastewater Treatment System. Water Sci. Technol. (G.B.). 23: 1553.

Chia, M.A., T.A. Lombardi and M. Da G.G. Melao. 2013. Growth and Biochemical Composition of Chlorella vulgaris in Different Growth Media. An. Acad. Bras. Cienc. 85(4): 24-37.

Davis, G.W., E.T. Heil and R. Rust. 2000. Ethanol Vehicle Cold Start Improvement When Using A Hydrogen Supplemented E85 Fuel. Energy Conversion Engineering Conference and Exhibit, Las Vegas, NV, (IECEC) $35^{\text {th }}$ Intersociety. 1:303-308.

Desikachary, C.V. 1959. Cyanophyta. ICAR, New Delhi. 61-75 pp.

Doemel, W.N. and T.D. Brock. 1971. The Physiological Ecology of Cyunidium caldarium. J. General Microbioz. 67: 17-32.

Elser, J.J., E.R. Marzolf and C.R. Goldman. 1990. Phosphorus and Nitrogen Limitation of Phytoplankton Growth in Freshwaters of North America: A Review and Critique of Experimental Enrichments. Canadian J. of Fisher. Aquat. Sci. 47:1468-1477. 
Harun, R., M.K. Danquah and G.M. Forde. 2010. Microalgal Biomass as A Fermentation Feedstock for Bio-ethanol Production. J. Chem. Technol. Biotechnol. 85: 199-203.

Jang, J.S., Y. Cho, G.T. Jeong and S.K. Kim. 2012. Optimization of Saccharification and Ethanol Production by Simultaneous Saccharification and Fermentation (SSF) from Seaweed, Saccharina japonica. Bioprocess and Biosystems Engineering. 35(1-2): 11-18.

Jones, C.S. and S.P. Mayfield. 2012. Algae Biofuels:Versatility for the Future of Bioenergy. Curr. Opin. Biotechnol. 23(3): 346-351.

Krichnavaruk, S., W. Loataweesup, S. Powtongsook and P. Pavasant. 2005. Optimal Growth Conditions and the Cultivation of Chaetoceros calcitrans in Airlift Photobioreactor. Chem. Engi. J. 105: 91-98.

Kumar, S., R. Gupta, G. Kumar, D. Sahoo and R.C. Kuhad. 2013. Bioethanol Production from Gracilaria verrucose, A Red alga in A Biorefinary Approach. Bioresour. Technol. 135: 150-156.

Lombardi, A.T. and M.T. Maldonado. 2011. The Effects of Copper on the Photosynthetic Response of Phaeocystic cordata. Photosynth. Res. 108: 77-87.

Marker, A.F.H., E.A. Nusch, H. Rai and B. Rieman. 1980. The Measurement of Photosynthetic Pigments in Freshwater and Standardization of Methods: Conclusions and Recommendations. Arch. Hydrobiol. Beih. Ergebn. Limnol. 14: 91-106.

Mayo, A.W. 1997. Effects of Temperature and pH on the Kinetic Growth of Unialga Chlorella vulgaris cultures Containing Bacteria. Water Env. Res. 69(1): 64-72.

Nagle, V.L., N.M. Mhalsekar and T.G. Jagtap. 2010. Isolation, Optimization and Characterization of Selected Cyanophycean Members. Ind. J. Marine Sci. 39(2): 212-214.

Nguyen, T.H.M. and V.H. Vu. 2012. Bioethanol production from Marine Algae biomass: Prospect and Troubles. J. Viet. Environ. 3(1):25-29.

Nigam, P.S. and A. Singh. 2011. Production of Liquid Biofuels from Renewable Resources. Prog. Ener. Combust. Sci. 37(1): 52-68.

Ong, S.C., C.Y. Kao, S.Y. Chiu, M.T. Tsai and C.S. Lin. 2010. Characterization of the Thermaltolerant Mutants of Chlorella sp. with High Growth Rate and Application in Outdoor Photobioreactor Cultivation. Bioresour. Technol. 101: 2880-2883.

Pirt, M.W. and S.J. Pirt. 1980. The Influence of Carbon Dioxide and Oxygen Partial Pressures on Chlorella Growth in Photosynthetic Steady-state Cultures. J. Gener. Microbiol. 119: 321326.

Rodolfi, L., G.C. Zittelli, N. Bassi, G. Padovani, N. Biondi, G. Bonini and M.R. Tredici. 2009. Microalgae for Oil: Strain Selection, Induction of Lipid Synthesis and Outdoor Mass Cultivation in a Low-Cost Photobioreactor. 102(1): 100-112.

Sahoo, D., S. Kumar, G. Elangbam and S.S. Devi. 2012. Biofuel Production from Algae Through Integrated Biorefinery. The Science of Algal Fuels: Springer. pp. 215-230.

Sato, N., N. Murata Y. Miura and N. Ueta. 1979. Effect of Growth Temperature on Lipid and FattyAcid Compositions in the Blue-green Algae, Anabaena variabilis and Anacystis nidulans. Biochimica. et Biophysico. Acta. 572: 19-28.

Sharma, R., G.P. Singh and V.K. Sharma. 2012. Effects of Culture Conditions on Growth and Biochemical Profile of Chlorella vulgaris. J. Plant Pathol. Microb. 131(3): 2-5.

Siddiqui, K.U., M.A. Islam, Z.U. Ahmed, Z.N.T. Begum, M.A. Hassan, M. Khondker, M.M. Rahman, S.M.H. Kabir, M. Ahmed, A.T.A. Ahmed, A.K.A. Rahman and E.U. Haque (eds.). 2007. Encyclopedia of Flora and Fauna of Bangladesh. Vol. 2. Cyanobacteria, Bacteria and Fungi. Asiat. Soc. Bangladesh, Dhaka. pp. 87-88.

Sinclair, C. and B.A. Whitton. 1977. Influence of Nutrient Deficiency on Hair Formation in the Rivulariaceae. Br. Phycol. J. 12: 297-313.

Song, H., E. Dotzauer, E. Thorin and J. Yan. 2013. Techno-economic Analysis of An Integrated Biorefinery System for Poly-generation of Power, Heat, Pellet and Bioethanol. Int. $J$. Ener. Res. 19: 578-593. 
Starmach, K. 1966. Cyanophyta-Sinice Glaucophyta-Gauophyty. Flra Säodkowodna Polski, Warszwa 3: 807.

Stewart, W.D.P. and J. R. Gallon.1980. Nitrogen fixation. Acad. Press, London. pp. 451.

Web 1: http://en.banglapedia.org/index.php?title=Biodiversity.

Wijanarko, A., Dianursanti, A.B. Witarto and R.W. Soemantojo. 2004. Effect of Photoperiodicity on $\mathrm{CO}_{2}$ Fixation by Chlorella Vulgaris Buitenzorg in Bubble Column Photobioreactor for Food Supplement Production. Makara. Seri. Teknologi. 8: 35-43.

Yoon, J.H., J. Shin and T.H. Park. 2008. Characterization of Factors Influencing the Growth of Anabaena variabilis in A Bubble Column Reactor. Bioresour. Technol. 99(5): 12041210.

(Revised copy received on 15/8/2016) 